\title{
Maternal Anemia during Pregnancy: A Longitudinal Cohort Study
}

Tebbani Fouzia*, Oulamara Hayet, Agli Abdenacer

Institute of Nutrition, Food and Food Technologies (INATAA), Laboratory of Nutrition and Food Technologies (LNTA)

*Corresponding Author: Tebbani Fouzia, Institute of Nutrition, Food and Food Technologies (INATAA), Laboratory of Nutrition and Food

Technologies (LNTA)

Received Date: Febuary 04, 2021; Accepted Date: March 15, 2021; Published Date: March 23,2021

Citation: Tebbani Fouzia, Oulamara Hayet, Agli Abdenacer (2021) Institute of Nutrition, Food and Food Technologies (INATAA), Laboratory of Nutrition and Food Technologies (LNTA) J. Women Health Care and Issues. 4(1); DOI:10.31579/2642-9756/041

Copyright: () 2021 Tebbani Fouzia, This is an open-access article distributed under the terms of the Creative Commons Attribution License, which permits unrestricted use, distribution, and reproduction in any medium, provided the original author and source are credited.

\section{Abstract}

Introduction: Anemia is a public health problem, prevalent among women of childbearing age. The aim was to determine the frequency of anemia in the first, second and third trimesters of pregnancy and to determine the associating factors in Algerian pregnant women.

Methods: We conducted a prospective and longitudinal cohort study of 300 pregnant women from December 2013 to July 2016. All consenting women attending antenatal clinics and having undergone complete blood count (CBC) were included in the study. Sociodemographic characteristics, individual's obstetrical history and the results of the $\mathrm{CBC}$ were collected. Anemia was defined according to the WHO criteria. After some descriptive statistics, we performed a bivariate analysis using the Chi-square test and Fisher exact probability test in order to determine the factors associated with gestational anemia.

Results: The rate of anemia was $28.0 \%$ in the first trimester, $32.3 \%$ in the second and $54.2 \%$ in the third one. It was more frequently observed during the third trimester of pregnancy $(\mathrm{P}<0.05)$. No significant difference was found between gestational anemia and socio-demographic factors. Women with inadequate gain were more anemic $(p=0.01)$. The average concentration of hemoglobin, hematocrit, VGM and platelets were lower in anemic pregnant women $(\mathrm{p}<0.0001)$.

Conclusion: The prevalence of anemia during pregnancy remains high. A better management of chronic diseases in pregnant women and of postpartum follow-up is necessary to treat anemia before a subsequent pregnancy.

Key words: pregnancy ; materanl anemia ; frequency ; associated factors

\section{Introduction}

Gestational anemia is a public health problem, prevalent among women of childbearing age. It is defined as a hemoglobin less than $11.0 \mathrm{~g} / \mathrm{dl}$ in the first and third trimesters of pregnancy and less than $10.5 \mathrm{~g} / \mathrm{dl}$ in the second trimester and it is one of the most common problems in obstetrics [1]. Anemia is a common problem concerning all the countries of the world. Some consulted studies report prevalences of $16.8 \%, 22.1 \%, 24.4$ $\% 32.8 \%, 41.6 \%$ and $100 \%$ respectively in Iran, Uganda, the United Kingdom, Ethiopia, India and Turkie [2, 3].

Gestational anemia can be explained primarily by a diet low in iron. Iron is an essential and vital nutrient for many cellular activities and vital for the early development of the nervous system. Thus, it is crucial for intrauterine and postnatal development [4]. Its origin may be due to several factors including single or combined deficiency of nutrients such as folic acid, vitamin B12 and iron deficiency is the most common cause of known nutritional anemia [5]. Nutritional deficiencies are still a common problem during pregnancy causing anemia. Gestational anemia is still considered a public health problem, because it is hazardous to both mother and fetus, and is associated with increased risk of maternal-fetal morbidity, as well as the nutritional status of child [6].

Maternal anemia is considered à risk factor for pregnancy and can be à cause of anemia in newborns, besides being related to higher miscarriage rate, intrauterine growth restriction, prematurity, fetal death and anemia in the first year of life due to low iron stores [7]. However, information on the incidence of anemia, especially in Algeria, are insufficient. The aim of this study was to determine the frequency of anemia in pregnant women in the first, second and third trimesters of pregnancy. Second objective was to determine the factors associated with anemia in Algerian pregnant women. Determining these factors will provide information on risk groups which will allow the implementation of more effective interventions to reduce anemia in pregnancy.

\section{Materials and Methods}

\section{Type, Duration and Period of the Study}

We conducted a prospective and longitudinal cohort study. We followed for 9 months a cohort of Algerian pregnant women attending antenatal clinics in early pregnancy. They were recruited at three different sites; at maternities, antenatal centers and private gynecologists in Constantine (Algeria), from December 2013 to July 2016. The participants were recruited and followed up longitudinally, once at the end of each trimester of pregnancy. The trimesters were defined as first (less than 16 weeks of amenorrhea), second (16-28 weeks of amenorrhea) and third (29-41 weeks of amenorrhea) [8].

\section{Study Population}




\section{Inclusion and Exclusion Criteria}

We included all pregnant women attending antenatal clinics during the study period, presenting for a pregnancy follow-up and agreeing to participate freely in the study. They were eligible for participation if they aged 18 years old and more, were healthy and mentally competent, entered prenatal care before the end of the first trimester of pregnancy and having a complete blood count (CBC).

We excluded women refusing to participate in the study, women with missing information on pre-pregnancy weight (in order to calculate prepregnancy BMI and weight gain), known diabetes, hypertension and anemia before pregnancy.

Pregnant women who met the inclusion criteria were informed of the objectives of the study. They agreed to be part of it until the birth of their babies. A signed consent was obtained from all women before starting the investigation

\section{Sampling and Sample Size}

During the study period, 1231 women came for the first pregnancy consultation. Of these, 703 did not agree to participate in the study, representing $57.1 \%$ of the total enrollment.

Of 528 women ( $42.9 \%$ of the total) responding favorably to the survey, we excluded 110 women who presented themselves after the date of starting weight measurement. Also, 52 women were excluded because they had a pre-pregnancy pathology (diabetes, high blood pressure, anemia, or endocrine pathology).

Among pregnant women meeting the inclusion criteria, 366 (69.3\%) were selected for the study. Of these women, 26 were excluded because they had a pregnancy stop and 26 dropped out. The sample that was selected for the first trimester of pregnancy consists of 314 women. In the second trimester, 14 women dropped out of the study. The final sample consisted of 300 pregnant women for the analysis of all data, representing a participation rate of $56.8 \%$ of women who agreed to participate in the study.

\section{Data Collected}

\section{Identification of Pregnant Women}

A standardized and pre-tested questionnaire was administered to pregnant women. All women were interviewed about their socio-demographic characteristics. For each pregnant woman we have raised the age, parity, level of education and standard of living. The level of education was divided into three categories according to the level of schooling: a low level (illiterate and primary), a medium level (middle and secondary plus training) and a high level (university).

For the standard of living, we proceeded to calculate a score reflecting the socio-economic level of our subjects. The approach consists in assigning a score, which reflects the woman's comfort level for each of the variables considered as predictive. The establishment indicators selected were: the overall monthly income of the household, the number of active persons per household that allows us to define a given economic coverage index by the number of active persons for each person living under the same roof. Also, the type of occupancy (owner or tenant), the occupancy rate per household, which is defined as the ratio between the size of the household (number of persons) and the number of rooms in the family dwelling and finally possessions owned (TV, freezer, stove, bath heater, air conditioner, microwave, washing machine, internet connection and car). The low standard of living score (SLS) was assigned to pregnant women whose total is less than 10 points; the average SLS for those with total points between 10 and 15 points and the high SLS group represents women who had more than 15 points.

The biological parameters were also searched: hemogram or NFS (hemoglobin level, mean corpuscular volume, red blood cells, white blood cells, hematocrit and platelets). Our data is based on blood tests of pregnant women.

\section{Anthropometric Measurements of the Pregnant Women}

Weight and height were measured according to a standard protocol [9, 10]. Pre-pregnancy weight was measured when the pregnant woman consulted at the early first trimester. During pregnancy, weight was measured at the end of each trimester (first, second and third) by using an electronic weighing balance Seca to the nearest $0.1 \mathrm{~kg}$. Height was measured in centimetres using a Seca toise, with a length of $2 \mathrm{~m}$ graduated in centimeters and with a precision of $0.1 \mathrm{~cm}$. Pregnant women were asked to maintain an upright and erect posture with their feet together and the back of their heels touching the pole of the anthropometer. The height was measured when the horizontal headpiece was lowered onto the women's head.

Pre-pregnancy body mass index (BMI) was calculated using a prepregnancy weight and height. Pre-pregnancy BMI was computed as weight $(\mathrm{kg})$ divided by square of measured height $(\mathrm{m})$. We categorized women's pre-pregnancy weight according to the World Health Organization (WHO) standards [10].

Weight gain (in $\mathrm{kg}$ ) at each prenatal visit (at the end of the first, second and third trimesters) and total GWG was collected. Weight gain of each pregnancy trimester was calculated by subtracting the previous trimester weight from the current trimester weight. Total weight gain was calculated as the weight of the woman measured at the end of pregnancy minus her starting weight. We used the 2009 IOM guidelines on GWG to categorize women's weight gain as below, within or above recommended [11]. These guidelines have also been adopted by Health Canada [12]. Weight gain assessment used recommendations of the Institute of Medicine (IOM) [11] according to the recommended weight gain ranges and to BMI categories: underweight: $12.5-18.0 \mathrm{Kg}$; adequate: $11.5-$ $16.0 \mathrm{Kg}$; overweight: $7.0-11.5 \mathrm{Kg}$ and obese: $7.0-9.0 \mathrm{Kg}$.

\section{Statistical Analyses}

Statistical analyses were performed using StatView software version5 (Abacus Concepts TM, Berkeley, USA). Continuous variables were described using mean \pm standard deviation and categorical variables were described using frequencies.

After some descriptive statistics, we performed a bivariate analysis using the Chi-square test for proportions, Student's $t$-test, or one-way ANOVA for continuous variables and multiple comparisons. . When it comes to comparing two percentages of low numbers, we used the exact test of Fisher in order to determine the factors associated with anemia. $\mathrm{P}$ value $<0.05$ was considered significant.

\section{Results}

A total of 300 pregnant women aged 19 to 43 years were participated in the study. The mean age was $30.3 \pm 5.0$ years. Of those, $82.0 \%$ were between 20 and 35 years old and only $18.0 \%$ were over 35 years old. Socio-demographic data of all subjects were presented in Table 1. A percentage of $35.7 \%$ were nulliparous. Mean spacing between pregnancies was $30.9 \pm 22.7$ months. $32.7 \%$ of women had a low standard of living and only $19.0 \%$ had a high standard of living. Mean prepregnancy BMI was $27.8 \pm 5.1 \mathrm{~kg} / \mathrm{m}^{2}$. Before pregnancy, $69.4 \%$ of women were overweight (of which $30.7 \%$ obese). None of the women was underweight before pregnancy (Table 1).

The mean overall gestational weight gain was $9.0 \pm 5.7 \mathrm{~kg}$. The mean rate of GWG in $1^{\text {st }}, 2^{\text {nd }}$ and $3^{\text {rd }}$ trimester was respectively $1.1 \pm 3.3 \mathrm{~kg}$, $4.6 \pm 3.0 \mathrm{~kg}$ and $3.3 \pm 2.5 \mathrm{~kg}$ (Table 1). According to the $2009 \mathrm{IOM}$ recommendations, we categorized weight gain into three categories: insufficient, adequate and excessive. The majority of women $(75.0 \%)$ had an abnormal weight gain at the end of pregnancy (of which $47.3 \%$ had an insufficient weight gain and $27.7 \%$ had an excessive weight gain) and only $25.0 \%$ of them had an adequate weight gain. 


\begin{tabular}{|c|c|c|}
\hline & Mean \pm SD or $N(\%)$ & Extreme values \\
\hline Maternal age (years) & $\begin{array}{c}30.3 \pm 5.0 \\
246(82.0 \%) \\
54(18.0 \%)\end{array}$ & $19-43$ \\
\hline $\begin{array}{r}\text { Nuliparity } \\
\text { Primiparity } \\
\text { Multiparity }\end{array}$ & $\begin{array}{c}1.0 \pm 1.0 \\
107(35.7 \%) \\
102(34.0 \%) \\
91(30.3 \%) \\
\end{array}$ & $0-4$ \\
\hline $\begin{aligned} & \text { Spacing between pregnancies (months) }<6 \text { months } \\
& 7 \text { to } 23 \text { months } \\
&>24 \text { months }\end{aligned}$ & $\begin{array}{c}30.9 \pm 22.7 \\
4(2.1 \%) \\
64(33.2 \%) \\
125(64.7 \%)\end{array}$ & $3-156$ \\
\hline Maternal education & $\begin{array}{l}102(34.0 \%) \\
87(29.0 \%) \\
111(37.0 \%)\end{array}$ & \\
\hline Socio-economic levelLow & $\begin{array}{l}98(32.7 \%) \\
145(48.3 \%) \\
57(19.0 \%)\end{array}$ & \\
\hline $\begin{array}{rr}\text { Pre-pregnancy BMI }\left(\mathrm{kg} / \mathrm{m}^{2}\right) & \\
& \text { Normal }(18.5-24.9) \\
\text { Overweight }(25-29.9) \\
\text { Obese }(\geq 30) \\
\end{array}$ & $\begin{array}{c}27.8 \pm 5.1 \\
92(30.7 \%) \\
116(38.7 \%) \\
92(30.7 \%) \\
\end{array}$ & $16.5-46.9$ \\
\hline $1^{\text {st }}$ Trimester GWG & $1.1 \pm 3.3$ & $-15.0 \_10.0$ \\
\hline $2^{\text {nd }}$ Trimester GWG & $4.6 \pm 3.0$ & $-2.3 \_17.6$ \\
\hline $3^{\text {rd }}$ Trimester GWG & $3.3 \pm 2.5$ & $-5.7 \_12.7$ \\
\hline $\begin{array}{r}\text { Insufficient } \\
\text { Normal } \\
\text { Excessive }\end{array}$ & $\begin{array}{c}9.0 \pm 5.7 \\
142(47.3 \%) \\
75(25.0 \%) \\
83(27.7 \%)\end{array}$ & $-3.8 \_24.0$ \\
\hline
\end{tabular}

Otherwise specified

BMI: body mass index

GWG: gestational weight gain

Table 1: Characteristic of women included in the studydata are mean \pm sd or $n(\%)$ unless

According to these data, we found that the rate of red blood cells, hematocrit and the rate of the average corpuscular volume of pregnant women were below the standards. The mean hemoglobin level was 11.3 $\pm 1.3 \mathrm{~g} / \mathrm{dl}$, with a rate of $58.0 \%$ of women who had an iron deficiency anemia (Table 2).

\begin{tabular}{|c|c|c|c|c|}
\hline Biological parameters & Mean \pm SD ou N (\%) & Min & Max & Standards \\
\hline White blood cells $\times 103 / \mathrm{mm3}$ & $8.2 \pm 2.6$ & 0.6 & 25.5 & $4.0-10.0$ \\
\hline Red blood cells ×106 / mm3 & $3.9 \pm 0.6$ & 3.0 & 6.2 & $4.00-6.2$ \\
\hline Hemoglobin (Hb) (g/dl) & $\begin{array}{c}11.3 \pm 1.3 \\
174(58.0 \%) \\
126(42.0 \%)\end{array}$ & 8.7 & 15.7 & $11.0-17.0$ \\
\hline Hematocrit (Ht) (\%) & $35.1 \pm 3.3$ & 27.1 & 46.6 & $36.0-55.0$ \\
\hline Platelets $\times 105 / \mathrm{mm3}$ & $223.6 \pm 57.4$ & 96.0 & 435.0 & $150-450$ \\
\hline VGM (fl) & $84.6 \pm 5.9$ & 65.2 & 109.0 & $85.0-100.0$ \\
\hline
\end{tabular}

$V G M=$ mean corpuscular volume; $f$ l= fentolitre.

WHO/CDC (2008) Worldwide Prevalence of Anemia 1993-2005 WHO Global Data base on Anemia, WHO Press, Geneva, Switzerland, 2008.

Table 2: Biological parameters of pregnant women.

The rate of anemia was $28.0 \%$ in the first trimester, $32.3 \%$ in the second and $54.2 \%$ in the third one. It was more frequently observed during the third trimester of pregnancy $(\mathrm{P}<0.05)$ (Figure 1$)$. 


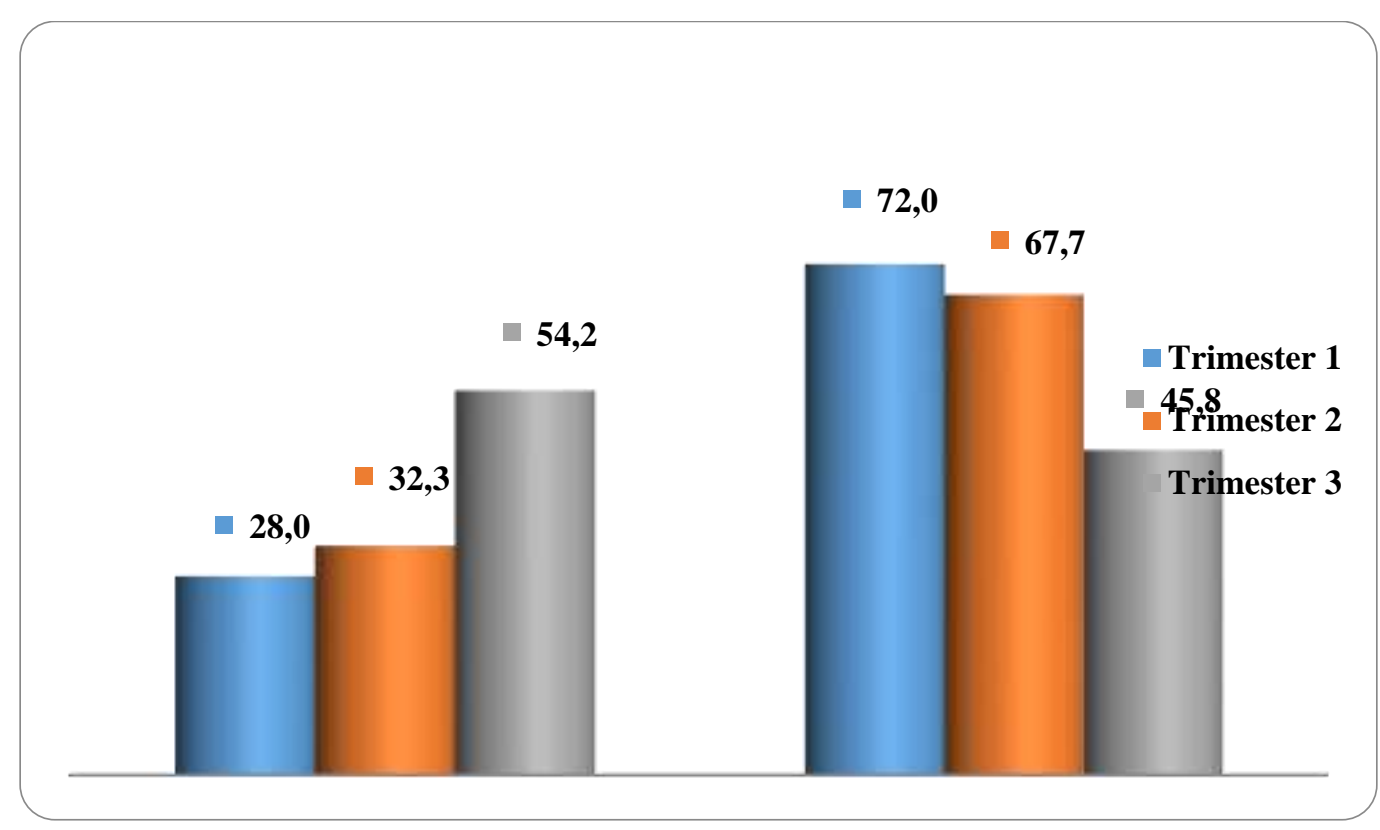

Figure 1: Distribution of anemic and non anemic women during the 3 trimesters of pregnancy.

In Table 3, we presented sociodemographic, obstetric, haematological and nutritional factors associated with gestational anemia. We found no significant difference between gestational anemia and socio-demographic factors such as age, education level and socioeconomic status. For parity, although not significant, primiparas were likely to be more anemic than nulliparas and multiparas. Regarding pre-gestational weight status, normoponderal women were more anemic than overweight and obese women $(\mathrm{p}=0.05)$. Concerning gestational weight gain, women with inadequate gain $(66.2 \%)$ were more anemic $(\mathrm{p}=0.01)$ than women with normal $(54.7 \%)$ and excessive $(47.0 \%)$ weight gain. For obstetric and haematological factors, the average concentration of hemoglobin (10.4 \pm 0.5 vs $12.5 \pm 0.9 ; \mathrm{p}<0.0001)$, hematocrit $(33.5 \pm 2.5$ vs $37.4 \pm 3.1$; $\mathrm{p}<0.0001)$, VGM $(214.4 \pm 53.0$ vs $236.1 \pm 61.0 ; \mathrm{p}<0.0001)$ and platelets $(83.4 \pm 6.2$ vs $86.2 \pm 5.1 ; \mathrm{p}<0.0001)$ were lower in anemic pregnant women compared with non anemic pregnant women.

\begin{tabular}{|c|c|c|c|}
\hline & $\begin{array}{c}\text { Anemic } \\
(\mathrm{N}=\mathbf{1 7 4})\end{array}$ & $\begin{array}{c}\text { Non-Anemic } \\
(\mathrm{N}=\mathbf{1 2 6})\end{array}$ & p-value* \\
\hline \multicolumn{4}{|l|}{ Maternal age (years) } \\
\hline $20-35$ & $141(57.3 \%)$ & $105(42.7 \%)$ & 0.6 \\
\hline$>35$ & $33(61.1 \%)$ & $21(38.9 \%)$ & \\
\hline \multicolumn{4}{|l|}{ Parity } \\
\hline Nuliparity & $58(54.2 \%)$ & $49(45.8 \%)$ & \\
\hline Primiparity & $68(66.7 \%)$ & $34(33.3 \%)$ & 0.09 \\
\hline Multiparity & $48(52.7 \%)$ & $43(47.3 \%)$ & \\
\hline \multicolumn{4}{|l|}{ Maternal education } \\
\hline Low & $57(55.9 \%)$ & $45(44.1 \%)$ & \\
\hline Average & $49(56.3 \%)$ & $38(43.7 \%)$ & 0.6 \\
\hline High & $68(61.3 \%)$ & $43(38.7 \%)$ & \\
\hline \multicolumn{4}{|l|}{ Socio-economic level } \\
\hline (2) & $60(61.2 \%)$ & $38(38.8 \%)$ & \\
\hline Average & $82(56.6 \%)$ & $63(43.4 \%)$ & 0.7 \\
\hline High & $32(56.1 \%)$ & $25(43.9 \%)$ & \\
\hline \multicolumn{4}{|l|}{ Pre-pregnancy BMI $\left(\mathrm{kg} / \mathrm{m}^{2}\right)$} \\
\hline Normal (18.5-24.9) & $61(66.3 \%)$ & $31(33.7 \%)$ & \\
\hline Overweight (25-29.9) & $68(58.6 \%)$ & $48(41.4 \%)$ & 0.05 \\
\hline Obese $(\geq 30)$ & $45(48.9 \%)$ & $47(51.1 \%)$ & \\
\hline \multicolumn{4}{|l|}{ Total GWG } \\
\hline Insufficient & $94(66.2 \%)$ & $48(33.8 \%)$ & 0.01 \\
\hline Adequate & $41(54.7 \%)$ & $34(45.3 \%)$ & \\
\hline Excessive & $39(47.0 \%)$ & $44(53.0 \%)$ & \\
\hline $\mathrm{GB} \times 103 / \mathrm{mm3}$ & $8.0 \pm 2.9$ & $8.5 \pm 2.2$ & 0.06 \\
\hline GR×106 / mm3 & $3.6 \pm 0.4$ & $4.4 \pm 0.5$ & $<0.0001$ \\
\hline $\mathrm{Hb}(\mathrm{g} / \mathrm{dl})$ & $10.4 \pm 0.5$ & $12.5 \pm 0.9$ & $<0.0001$ \\
\hline
\end{tabular}




\begin{tabular}{|lc|c|c|c|}
\hline & $\mathrm{Hb}<11$ & $174(100 \%)$ & $0(0)$ & $<0.0001$ \\
& $\mathrm{Hb} \geq 11$ & $0(0)$ & $126(100 \%)$ & \\
\hline Ht (\%) & & $33.5 \pm 2.5$ & $37.4 \pm 3.1$ & $<0.0001$ \\
\hline Plaquettex $\mathbf{1 0 5} / \mathbf{m m 3}$ & & $214.4 \pm 53.0$ & $236.1 \pm 61.0$ & 0.0012 \\
\hline VGM (fl) & & $83.4 \pm 6.2$ & $86.2 \pm 5.1$ & $<0.0001$ \\
\hline
\end{tabular}

Gestational anemia

Data are mean \pm SD or $n(\%)$ unless otherwise specified

BMI: body mass index

* Comparisons performed using ANOVA analysis and Chi2 test.

Table 3: Sociodemographic, obstetric, haematological and nutritional factors associated with

\section{Discussion}

The present study is a longitudinal and prospective study about maternal anemia in pregnant women in the first, second and third trimesters of pregnancy. Second objective was to determine the factors associated with anemia in Algerian pregnant women. Nowadays, maternal anemia is considered as a public health problem in the world, especially in developing countries. For example, the prevalence of anemia among pregnant women is $52 \%$ in developing countries and $22.5 \%$ in developed countries [13]. This study revealed that anemia was common in pregnant women: $58.0 \%$ of the patients recruited had gestational anemia. In à study in Sidi Bel Abbes (Algeria), [14], they found that the prevalence of gestational anemia was $74.0 \%$. This percentage was higher than that observed in our population. Studies in developing countries on pregnancy-induced anemia revealed a high prevalence, up to more than $50.0 \%[15]$.

The WHO considers anemia in pregnant women as a serious public health problem when the prevalence is greater than $40 \%$ [16]. The frequency of anemia in this study $(58.0 \%)$ was consistent with that expected for developing nations, being classified as severe in epidemiological scale (> $40 \%$ ). The same was observed in other developing countries, such as in eastern Ethiopia [17] and China [18], which had a frequency of anemic pregnant women of $43.9 \%$ and $58.6 \%$, respectively, while in developed countries, this prevalence is much lower $(\leq 20 \%)$ [19].

Prevalence of anemia was different during all trimesters of pregnancy. The highest prevalence was found in the $3^{\text {rd }}$ trimester of pregnancy; it was $28.0 \%$ in T1, 32.3 \% in T2 and $54.2 \%$ in T3. Our results were similar with other studies which found that anemia was even stronger as the age of pregnancy is advanced [20,21]. Contrary to our results, a meta-analysis that had been conducted in Iran in 2015, found that the prevalence of anemia was estimated to $19.6 \%$ in the first trimester, $10.1 \%$ in the second trimester and $16.1 \%$ in the third trimester, respectively [22]. The results of this study showed that in Algeria, anemia is still a public health problem that is far from being resolved and that might be caused by the combination of several factors.

The age of the pregnant woman did not seem to have an effect on gestational anemia. These results were in agreement with some studies that found no relationship between maternal age and gestational anemia [23]. Some other studies have found an increase in the prevalence of anemia in teen pregnancy [24]. Adolescent pregnant woment were not represented in our study (0 cases). Moreover, there was no significant association between the occurrence of anemia and different age groups, as in the work of Taner et al [25] and Nwizu et al [26].

We found no significant difference between gestational anemia and sociodemographic factors, such as education level and standard of living. Women with a university level were more anemic than women with average and low levels, however the difference was not significant. Bekele et al [27] did not find an association between education level and anemia in pregnant women either. Women with a low standard of living were likely to be more anemic than women with a high level, however the difference was not statistically significant. Low socioeconomic level was associated with anemia in pregnancy [27].
For parity, although not significant, primiparas women were likely to be more anemic than nulliparas and multiparas. Some studies [28] found that the risk increases with parity. This can be explained by the lack of compensation for losses and the depletion of reserves recorded in previous pregnancies and breastfeeding. This result was contradictory to that of other African studies, which find a higher prevalence in nulliparas and attribute it to their increased susceptibility to malaria [26].

Regarding pre-gestational weight status, normoponderal women $(66.3 \%)$ were more anemic than overweight $(58.6 \%)$ and obese women $(48.9 \%)$ $(\mathrm{p}=0.05)$. Studies contradicted each other on this point. The SEBIRE study published in the British Journal of Obstetrics and Gynecology in 2001 found that women who were underweight were more likely to be anemic during pregnancy (OR = 1.25 IC 99\% [1.19-1.30]) [33]. CHOI in its study in South Korea, grouped all hematological pathologies to have a larger number, however, despite a tendency to increase, it had not shown significant difference between the two populations $(\mathrm{OR}=2), 60[0.72$ 9.40]) [34].

Concerning gestational weight gain, women with inadequate gain (66.2 $\%)$ were more anemic $(\mathrm{p}=0.01)$ than women with normal $(54.7 \%)$ and excessive $(47.0 \%)$ weight gain. In our study, total gestational weight gain was a risk factor for gestational anemia. The rate of anemia was significantly higher in women with low weight gain (61.7\%), compared to women with excessive weight gain $(44.3 \%)$ and normal weight gain $(57.3 \%)(p=0.04)$. Some authors have shown that iron deficiency can lead to insufficient gestational weight gain [35].

For the diagnosis of anemia in populations, hemoglobin and hematocrit were generally used. The importance of these indicators during pregnancy should be highlighted, considering that they were frequently used as a screening test $[29,30]$. In our study, the average concentration of hemoglobin $(10.4 \pm 0.5$ vs $12.5 \pm 0.9 ; \mathrm{p}<0.0001)$, hematocrit $(33.5 \pm 2.5$ vs $37.4 \pm 3.1 ; \mathrm{p}<0.0001)$, VGM $(214.4 \pm 53.0$ vs $236.1 \pm 61.0 ; \mathrm{p}<$ $0.0001)$ and platelets $(83.4 \pm 6.2$ vs $86.2 \pm 5.1 ; \mathrm{p}<0.0001)$ were lower in anemic pregnant women compared with non anemic pregnant women. A U-shaped distribution has been shown between hemoglobin concentration and pregnancy complications [31, 32]. This means that the reduction of hemoglobin (less than $11 \mathrm{~g} / \mathrm{dL}$ ) lead to complications such as preterm delivery, intrauterine growth restriction and increased blood pressure Intrauterine growth retardation [32].

\section{Conclusion}

The rate of maternal anemia during pregnancy remains high. In the first and the last trimester of pregnancy, it can be considered as a risk factor for pregnancy outcomes and must be treated as an advance. Therfore, There is an increasing need for public health strategies to educate the population as to the need for a healthy diet and iron supplementation before conception, or at least at the beginning of pregnancy. Mothers should receive appropriate nutritional advice and supplementation at their first point of contact with healthcare professionals.

\section{Conflict of Interest}

The authors have no conflicts of interest. 


\section{References}

1. WHO/CDC. Worldwide Prevalence of Anemia 1993-2005 WHO Global Data base on Anemia, WHO Press, Geneva, Switzerland, 2008.

2. Mardania Mahnaz, Rezapourb Sadegh, Ahmadipourb Shokoufeh, Mohsenzadehb Azam AH, Khalkhali Rad AH, Roostac Sajjad, Ebrahimzadeh Farzad. Prevalence of anemia and its risk factors among pregnant women in Khorramabad (Iran) 2010-2014. J Matern Fetal Neonatal Med. 2016;26:1-4.

3. Vemulapalli B, Rao KK. Prevalence of anemia among pregnant women of rural community in Vizianagram, North coastal Andhra Pradesh, India. Asian Journal of Medical Science. 2014;5(2):21-25.

4. Whitney E, Rolfes SR. Nutricao: entendendo os nutrientes. 10a ed. Sao Paulo: Cengage Learning, 2008.

5. Scholl T O. Maternal iron status: relation to fetal growth, length of gestation and the neonate's iron endowment. Rev Nutr. 2011; 69 Suppl1 : S23-29.

6. Tolentino K \& Friedman JF. An update on anemia in less developed countries. American Journal of Tropical Medicine and Hygiene 2007 ; 77, 44-51.

7. Wojtyla C, Bilinski P, Paprzycki P, Warzocha K. Haematological parameters in postpartum women and their babies in Poland: comparison of urban and rural areas. Ann Agr Env Med. 2011;18(2) ; 380-385.

8. CDC. Pregnancy nutrition surveillance nation. Summary of trends in maternal health indictors, 2011.

9. Cogill B. Guide to measuring anthropometric indicators. Technical assis- tance project for food and nutrition. Washinghton, DC: Academy for Development and Education; 2003. p. 104.

10. WHO, Expert Committee. Physical status: the use and interpretation of anthropometry. Geneva: WHO, technical report; 1995 [series 854].

11. Institute of Medicine (US) and National Research Council (US) Commit- tee to Reexamine IOM Pregnancy Weight Guidelines, Rasmussen KM, Yaktine AL. Weight gain during pregnancy: reexamining the guidelines. Washington (DC): The National Academies Press (US); 2009.

12. Health Canada. Prenatal nutrition guidelines for health professionals. Gestational weight gain. Health Canada; 2010..

13. Morrone A, Nosotti L, Piombo L, Scardella P, Spada R, Pitidis A. Iron deficiency anaemia prevalence in a population of immigrated women in Italy. European Journal of Public Health 2010; 22(2): 256-262.

14. Demmouche A, Moulessehoul S. (2010) Prévalence de l'anémie ferriprive au cours de la grossesse dans la wilaya de Sidi Bel Abbes (ouest de l'Algérie). Antropo 2010; 21: 39-48.

15. Sato APS, Fujimori E, Szarfarc SC, Borges ALV, Tsunechiro MA. Food consumption and iron intake of pregnant and reproductive aged women. Revista Latino-Americana de Enfermagem 2010; 18: 247-254.

16. Kraemer K, Zimmermann MB, editors. Nutritional anemia. Basel (Switzewrland): Sight and Life Press; 2007.

17. Kedir H, Berhane Y, Worku A. chewing and restrictive dietary behaviors are associated with anemia among pregnant women in high prevalence rural communities in eastern Ethiopia. PLoS One. 2013; 4;8(11):e78601.

18. Ma AG, Schouten E, Wang Y, Xu RX, Zheng MC, Li Y, et al. Anemia prevalence among pregnant women and birth weight in five areas in China. Med Princ Pract. 2009;18(5):368-372.

19. Bener A, Al-Nufal M, Vachhani PJ, Ali AI, Samson N, Saleh NM. Maternal complications and neonatal outcome in Arab women of a fast developing country. J Family Community Med. 2013;20(1):27-34.

20. Heng W., Xuencuen C., Wenguang W. Nutritional status of gestating Chinese women and its influence upon neonates, with emphasis on iron. Nutrition-Resarch (USA) 1990, 10, (5): 493502.),

21. Allen LH. Nutrition supplementation for the pregnant women. Clin. Obstet. Gynecol 1994, 37:587-595

22. Sayehmiri K, Darvishi Z, Azami M, Qavam S. The prevalence of anemia in the first quarter, the second and third pregnancy a systematic review and meta-analysis. Iran $\mathrm{J}$ of med Midwifery and Women Mashhad 2015; 168(18): 7-15.

23. Solange Augusta de Sá et al. Anemia in pregnancy: impact on intrauterine child's growth. Nutr Hosp. 2015;32(5):2071-2079

24. Soula O, Carles G, Largeaud M, El Guindi W, Montoya Y. Pregnancy and delivery among adolescents under 15: a study of 181 cases in French Guiana. J Gynecol Obstet Biol Reprod (Paris). 2006 Feb;35(1):53-61.

25. Taner Cüneyt Eftal, Ekin Atalay, Solmaz Ulal, Gezer Cenk, Çetin Birgül, Keleşoğlu Mustafa, Erpala Merve Bayrak, Özeren Mehmet. Prevalence and risk factors of anemia in pregnancy. $\mathbf{J}$ Turk Ger Gynecol Assoc. 2015; 16(4):231-236.

26. Nwizu EN, Lliyasu Z, Ibrahim SA, Galadanci H. Sociodemographic and maternal factors in anemia in pregnancy at booking in Kano, Northern Nigeria. Afr J Repord Health. 2011;15(4):33-41.

27. Bekele Alemayehu, Tilahun Marelign, Mekuria Aleme. Prevalence of Anemia and Its Associated Factors among Pregnant Women Attending Antenatal Care in Health Institutions of Arba Minch Town, Gamo Gofa Zone, Ethiopia: A Cross-Sectional Study. Anemia. 2016;2016:1073192 Epub 2016 Feb 22.

28. Upadhyay C, Upadhyay N. Effect of anemia on pregnancy outcome: a prospective study at tertiary care hospital. Int J Reprod Contracept Obstet Gynecol 2017;6: 5379-5383.

29. Massucheti L, Corso ACT, Moreira EAM. Prevalencia de anemia em gestantes atendidas na rede publica de saude do municipio de Florianopolis (SC). Cad Saúde Coletiva 2009; 10:417-431.

30. Dani C, Rossetto S, Castro SM, Wagner SC. Prevalencia da anemia e deficiencias nutricionais, atraves de diferentes parametros laboratoriais, em mulheres gravidas atendidas em dois servicos de saude publica no Rio Grande do Sul. Rev Bras Anal Clin. 2008; 40:171-175.

31. Scalon KS, Yip R, Schieve LA, Congwell SE. Hiegh and low hemoglobin levels during pregnancy : different risk for preterm birth and small for gestation age obstetcynecol 2000; 96(5): 741-748.

32. Chang SC, O'Brien KO, Nathanson MS, Mancini J, Witter FR. Hemoglobin concentrations influence birth outcomes in pregnant African-American adolescents. Journal of Nutrition 2003; 133(7): 2348-2355.

33. Sebire NJ, Jolly M, Harris J, Regan L, Robinson S. Is maternal underweight really a risk factor for adverse pregnancy outcome? A population-based study in London. Br J Obstet Gynaecol 2001; 108(1):61-66.

34. Choi S-K, Park IY, Shin JC. The effects of pre-pregnancy body mass index and gestational weight gain on perinatal outcomes in Korean women: a retrospective cohort study. Reprod Biol Endocrinol 2011 [consulté le 6 nov 2013];9(6).

35. Foulhy C. L'alimentation de la femme enceinte et allaitante. Vocation Sage-femme 2007; $56: 8$ - 12. 
This work is licensed under Creative

Commons Attribution 4.0 License

\section{To Submit Your Article Click Here: Submit Manuscript}

DOI:10.31579/2642-9756/045
Ready to submit your research? Choose Auctores and benefit from:

* fast, convenient online submission

* rigorous peer review by experienced research in your field

* rapid publication on acceptance

* authors retain copyrights

* unique DOI for all articles

* immediate, unrestricted online access

At Auctores, research is always in progress.

Learn more www.auctoresonline.org/journals/women-health-care-andissues 